\title{
Occurrence and stability of plasmids in Aeromonas salmonicida ss salmonicida isolated from salmonids with furunculosis
}

\author{
Henning Sørum ${ }^{1}$, Jo Haldor Kvello ${ }^{2}$, Tore Håstein ${ }^{3}$ \\ ${ }^{1}$ Norwegian College of Veterinary Medicine, Post Box 8146 Dep., N-0033 Oslo, Norway \\ ${ }^{2}$ Army Medical Service, Pharmaceutical Department, N-0753 Oslo, Norway \\ ${ }^{3}$ National Veterinary Institute, Post Box 8156 Dep., N-0033 Oslo, Norway
}

\begin{abstract}
The fish pathogen Aeromonas salmonicida ss salmonicida was first recorded in Norwegian farmed salmonids in 1985. Plasmid profiling was investigated as a possible method for use in epizootiological work. A total of 383 different isolates was investigated over a period of 6 yr. Plasmid profiling of the isolates revealed 1 to 4 large plasmid bands varying in size from 52 to $105 \mathrm{MDa}$. Repeated plasmid screening of isolates (even a single isolate) grown under varying conditions and DNA-DNA hybridization, suggested that only one large plasmid was present but that it could occur in up to 4 configurations. An alternative possibility was that there were 4 large plasmids, each sharing common sequences, but that the individual plasmids did not always replicate to the stage where visible bands were produced. Different growth media or length of incubation of culture had no apparent effect on the occurrence of the different large plasmid bands. The DNA of the large plasmid bands was susceptible to mechanical stress and UV-light exposure. A group of 4 small plasmids of 3.4, 3.5, 3.6 and 4.2 MDa characterized most of the isolates whereas only $7.3 \%$ of the isolates contained plasmids of intermediate size $(6.5$ to $40 \mathrm{MDa})$. Overall, the plasmid content of $A$. salmonicida ss salmonicida seemed to be very constant worldwide, and thus plasmids in this organism would generally be of little epizootiological value.
\end{abstract}

\section{INTRODUCTION}

Plasmids often represent the most variable part of the genome in a bacterial cell (Elmerich 1990). This variation in the plasmid profile has been used to subgroup isolates in epidemiological studies of outbreaks of salmonellosis among both humans and animals (Holmberg et al. 1984, Olsvik et al. 1985, Sorum et al. 1990). In bacterial fish pathogens, plasmid variation also occurs within species and subspecies. For example, the bacterium causing cold-water vibriosis, Vibrio salmonicida, contains from one to several different plasmids. However, the variation noted in plasmid profiles among isolates was limited, with a pair of profiles predominating (Sørum et al. 1988). Identical plasmid profiles were found in isolates of $V$. salmonicida from all areas in the eastern and western Atlantic Ocean from which the bacterium has been isolated (Sørum et al. 1993). On the other hand, isolates of atypical Aeromonas salmonicida, an organism that can cause disease in farmed fish (Austin \& Austin 1987) show considerable plasmid variation. Plasmid profiling among isolates of atypical $A$. salmonicida may be useful for dividing the isolates into subgroups (Bast et al. 1988, Belland \& Trust 1989, Sørum unpubl. results)

The primary aim of this inyestigation was to evalute the use of plasmid profiling in epizootiological work in outbreaks of furunculosis in salmonids caused by Aeromonas salmonicida ss salmonicida. The investigation was started in 1985 when furunculosis was thought to have been introduced into Norwegian salmonid farming with the import of infected smolts from Scotland. The initial results showed an apparent variation in plasmid profiles of the A. salmonicida ss salmonicida isolates. The variation was, however, found to be inconsistent, even within isolates, and thus plasmids proved, at the time, to be ineffective as an epizootiological tool. Other workers have shown that the plasmid content of $A$. salmonicida ss salmonicida is homogeneous (Bast et al 1988, Belland \& Trust 1989). 
In particular, the small plasmids have been considered to be characteristic for $A$. salmonicida ss salmonicida. However, little attention has been paid to the larger plasmids of this bacterium. Also, the number of strains of A. salmonicida ss salmonicida investigated in earlier studies has been small (Toranzo et al. 1983, Hackett et al. 1984, Bast et al. 1988, Belland \& Trust 1989).

In addition to the primary goal of evaluating the epizootiological use of plasmid profiling in a large collection of clinical isolates of Aeromonas salmonicida ss salmonicida, a second aim of this study was therefore to analyze the stability of the large plasmids of the bacterium and to study the factors influencing this stability

\section{MATERIALS AND METHODS}

Bacterial strains. A total of 383 isolates of Aeromonas salmonicidass salmonicida was included in this study. The Norwegian isolates were obtained from the kidney or gross lesions of farmed Atlantic salmon Salmo salar or rainbow trout Oncorhynchus mykiss suffering from furunculosis. Isolates from other countries and a reference isolate are listed in Table 1.

The Norwegian isolates were originally grown on $5 \%$ bovine blood agar incubated aerobically at $15^{\circ} \mathrm{C}$ for $2 \mathrm{~d}$. Subsequently, the isolates were grown on Luria agar (LA), in Luria broth (LB), or in Brain Heart Infusion Broth (Difco Laboratories, Detroit, MI, USA) (BHIB) at 15 or $22^{\circ} \mathrm{C}$. The isolates were stored on LA slants at $4{ }^{\circ} \mathrm{C}$ and at $-70^{\circ} \mathrm{C}$ in LB supplemented with $10 \%$ glycerol. When using stored isolates, $5 \%$ bovine blood agar was the medium used for regrowth. LB was the routine medium used for culture of all isolates for plasmid isolation

Plasmid isolation. Plasmids were isolated using 2 different small-scale procedures. A modified method of Kado \& Liu (1981) was employed for all isolates one or more times. Modifications involved the incubation conditions with the lysis solution, and the phenol/chloroform extraction step. The time of incubation with the lysis solution was varied from a few minutes to more than $1 \mathrm{~h}$. The temperature for incubation with the lysis solution varied from 55 to $65^{\circ} \mathrm{C}$. In the phenol extraction step, both acid and buffered phenol at pH 7.0 were used, and the phenol contact time was varied. Plasmid isolation was performed for the first time as close to the primary isolation as possible. The mini-Birnboim procedure (Birnboim \& Doly 1979) was also used in plasmid isolation from selected strains in addition to the modified method of Kado \& Liu (1981). A large-scale SDS-method (Maniatis et al. 1982) was used to isolate plasmid DNA from strain 2921/89. The plasmid DNA was run in a cesium chloride/ethidium bromide $(\mathrm{CsCl} / \mathrm{EtBr})$ gradient to purify it.
Table 1 Aeromonas salmonicida ss salmonicida isolates (46) obtained from countries other than Norway

\begin{tabular}{|c|c|c|}
\hline Isolate & Country & Year of isolation \\
\hline \multicolumn{3}{|l|}{ ATCC 14174} \\
\hline 2827/85, B2402/85 & Sweden & 1985 \\
\hline $2827 / 85$, B2403/85 & Sweden & 1985 \\
\hline $30 / 87$ & Sweden & 1987 \\
\hline $78 / 87$ & Sweden & 1987 \\
\hline $417 / 87$ & Sweden & 1987 \\
\hline $428 / 87$ & Sweden & 1987 \\
\hline $524 / 87$ & Sweden & 1987 \\
\hline 2755/85 Rindsholm & Denmark & 1985 \\
\hline 2755/85 Veldal & Denmark & 1985 \\
\hline $33 D K$ & Denmark & 1990 \\
\hline $34 \mathrm{DK}$ & Denmark & 1990 \\
\hline $35 \mathrm{DK}$ & Denmark & 1990 \\
\hline $37 D K$ & Denmark & 1990 \\
\hline $38 \mathrm{DK}$ & Denmark & 1990 \\
\hline $39 D K$ & Denmark & 1990 \\
\hline $40 D K$ & Denmark & 1990 \\
\hline $41 \mathrm{DK}$ & Denmark & 1990 \\
\hline $42 \mathrm{DK}$ & Denmark & 1990 \\
\hline $43 \mathrm{DK}$ & Denmark & 1990 \\
\hline $260 / 86$ & Finland & 1986 \\
\hline $261 / 86$ & Finland & 1986 \\
\hline $265 / 86$ & Finland & 1986 \\
\hline $266 / 86$ & Finland & 1986 \\
\hline $275 / 86$ & Finland & 1986 \\
\hline $1244 / 86$ & Finland & 1986 \\
\hline $1302 / 86$ & Finland & 1986 \\
\hline 1262 & Finland & 1986 \\
\hline 1153 & Finland & 1986 \\
\hline $4948 / 86$ & Finland & 1986 \\
\hline $250 / 87$ & Scotland & 1987 \\
\hline $85 / 09 / 2078$ & Scotland & 1985 \\
\hline $3010 / 85, \mathrm{~B} 83016 \mathrm{~L}$ & Scotland & 1983 \\
\hline $3010 / 85, \mathrm{~B} 83016$ & Scotland & 1.983 \\
\hline $3010 / 85, \mathrm{~B} 85093$ & Scotland & 1985 \\
\hline $3010 / 85, \mathrm{~B} 850100$ & Scotland & 1985 \\
\hline $3010 / 85, \mathrm{~B} 85112$ & Scotland & 1985 \\
\hline Ft $X$ & Scotland & \\
\hline $2893 / 85$ & Switzerland & 1.985 \\
\hline 425/86 Fi 20/86 & Switzerland & 1986 \\
\hline $2754 / 85,72 / 78$ & France & 1985 \\
\hline $2754 / 85,88 / 68$ & France & 1985 \\
\hline $3001 / 85,41 / 84 \mathrm{R}$ & France & 1984 \\
\hline 2834/85, A140 85 & Ireland & 1985 \\
\hline $2834 / 85$, A 14185 & Ireland & 1985 \\
\hline $123 / 86$ & USA & 1986 \\
\hline
\end{tabular}

Plasmid electrophoresis. The plasmids from all isolates were separated by electrophoresis in $1 \%$ agarose gel in a vertical gel apparatus. The buffer used was Tris-borate-EDTA (TBE) $(0.089 \mathrm{M}$ boric acid, $0.0025 \mathrm{M}$ EDTA, $0.089 \mathrm{M}$ Tris, $\mathrm{pH} 8.0$ ). Electrophoresis was carried out at $120 \mathrm{~V}$ for $3.5 \mathrm{~h}$. Alternatively, for better separation of the small plasmids, $0.8 \%$ agarose gel in a horizontal gel apparatus was used for a selected group of isolates. In this case, electrophoresis was carried out at $50 \mathrm{~V}$ for $8 \mathrm{~h}$ using Tris-acetate buffer $(0.005 \mathrm{M} \mathrm{NaAc}$, 
0.001 M EDTA, 0.04 M Tris, pH 7.8). Gels were stained with ethidium bromide $(\mathrm{EtBr})$ and photographed under UV light. The sizes of the plasmids were estimated by including Escherichia coli reference plasmids of known size in the gels. The plasmids Sa (23 MDa), RP4 (34 MDa), R1 (62 MDa), a strain containing pDK9 (140 MDa) and a plasmid of $105 \mathrm{MDa}$, and E. coli V517 with plasmids of $1.4,1.8,2.0,2.6,3.4,3.7,4.8$ and 35.8 MDa (Macrina et al. 1978) were used as standards.

Two-dimensional electrophoresis, as described by Hintermann et al. (1981), was used to distinguish between covalently closed circular plasmid DNA and relaxed, open, circular plasmid DNA. After separating a plasmid preparation in a horizontal $0.8 \%$ agarose gel in Tris-acetate buffer, the gel was stained with $\mathrm{EtBr}$ as described, and photographed. The gel was then exposed to UV light from a hand lamp (UV-50 series, UVP International, Inc., San Gabriel, CA, USA) emitting short wave $(254 \mathrm{~nm})$ radiation, at a distance of 15 to $30 \mathrm{~cm}$ for $5 \mathrm{~min}$. The gel was then turned $90^{\circ}$, and subjected to electrophoresis for another $8 \mathrm{~h}$ at $50 \mathrm{~V}$ before being restained and photographed under UV light.

Variation in growth conditions and treatment of the isolated plasmid DNA. Efforts were made to determine whether plasmid profiles varied as a result of different growth or lysis conditions of the bacteria, or after exposure of the plasmid DNA to UV illumination or mechanical stress.

To test the effect of growth conditions, 3 strains of Aeromonas salmonicida ss salmonicida were grown aerobically in 3 different broth media for $48 \mathrm{~h}$ at $15^{\circ} \mathrm{C}$ before harvesting the cells. The media were BHIB (Difco), LB, and seawater yeast peptone (SWYP) broth. SWYP broth was prepared with artificial seawater as described by Hendrie et al. (1970). In addition, 2 strains (one from the spleen; the other from a muscle lesion of the same fish), which had shown varying plasmid profiles on repeated plasmid isolations, were grown aerobically on LB at $15^{\circ} \mathrm{C}$, and harvested at different points in the growth curve (i.e. after 20,22.5, 43.5, 47 and $67 \mathrm{~h})$.

To investigate combined effects on the plasmid profiles of the lysis step and the other steps of the plasmid DNA isolation procedures, cells were harvested from 2 colonies on an agar plate and lysed directly in the wells of an agarose gel. The colony material was mixed with $15 \mu \mathrm{l}$ of a lysozyme solution [lysozyme, $7500 \mathrm{U} \mathrm{ml}^{-1}$; RNase I, $0.3 \mathrm{U} \mathrm{ml}^{-1} ; 0.05 \%$ bromphenol blue in TBE buffer; $20 \%$ Ficoll Type 400 (Pharmacia, Uppsala, Sweden)] which had been previously placed in the empty agarose well. The suspension was incubated at room temperature for $5 \mathrm{~min}$ before a $30 \mu \mathrm{l}$ layer of $0.2 \%$ SDS in TBE buffer and $10 \%$ Ficoll Type 400 was carefully placed on top of the bacterial suspension.
After a gentle mixing in the well, a $100 \mu l$ volume of a mixture of $0.2 \%$ SDS and $5 \%$ Ficoll Type 400 was added as an overlay without disturbing the contents of the well. The wells were sealed with hot agarose, and the gels run in TBE buffer.

To test whether mechanical stress during isolation procedures produced conformational changes in the plasmid DNA, resulting in more than one band from the same plasmid, plasmid DNA was flushed through plastic pipettes and syringe needles $(25 \mathrm{G} \times 5 / 8)$ a varying number of times before the samples were electrophoresed as described.

To investigate the effect of UV illumination on plasmid DNA, plasmid DNA samples were spotted in droplets on a plastic sheet and illuminated with UV light of $254 \mathrm{~nm}$ from a hand-lamp (UV-50 series, UVP International, Inc., San Gabriel, CA, USA) for 7 min at a distance of $10 \mathrm{~cm}$. The samples were then electrophoresed as described.

DNA-DNA hybridization. Gels with separated plasmid DNA were dried in a gel drier (Bio Rad, Model 443, Slab Dryer, Bio Rad Laboratories, Richmond, CA, USA) and stored at room temperature. Probe DNA was prepared from plasmid DNA of Aeromonas salmonicida ss salmonicida isolate $2921 / 89$ purified in a $\mathrm{CsCl} / \mathrm{EtBr}$ gradient, and separated in low melting point agarose (Sea Plaque GTG agarose, FMC BioProducts Rockland, ME, USA) (LMA) on a horizontal gel apparatus. This strain had only one large plasmid band of $52 \mathrm{MDa}$ which was excised from the LMA gel. The plasmid DNA was labelled with ${ }^{32} \mathrm{P}$ directly in the LMA using an oligolabelling kit (Bethesda Research Laboratories, Inc, Gaithersburg, MD, USA). Hybridization tests were performed at $42^{\circ} \mathrm{C}$ overnight without any prehybridization. The gels were washed in $5 \times \mathrm{SSC}, 0.1 \% \operatorname{SDS}$ at $65^{\circ} \mathrm{C}$. They were then wrapped in thin plastic, and X-ray films (Kodak XR, Rochester, NY, USA) were exposed to them for $2 \mathrm{~d}$.

\section{RESULTS}

All the isolates in the collection had one or more large plasmid bands sized 52,72, 85 or $105 \mathrm{MDa}$, some isolates yielding all 4 of the large plasmid bands (Fig. 1). This variation in the large plasmid band profiles occurred even in isolates from the same fish farm. Even isolates obtained from the kidney and muscle lesions of the same diseased fish showed variation in the number and size of their large plasmid bands. During one disease outbreak, isolates of Aeromonas salmonicida ss salmonicida were isolated from the kidney, the spleen, and from muscle lesions in 6 fish with clinical signs of furunculosis. On original testing, only isolates from 4 fish gave identical plasmid profiles. On 
A

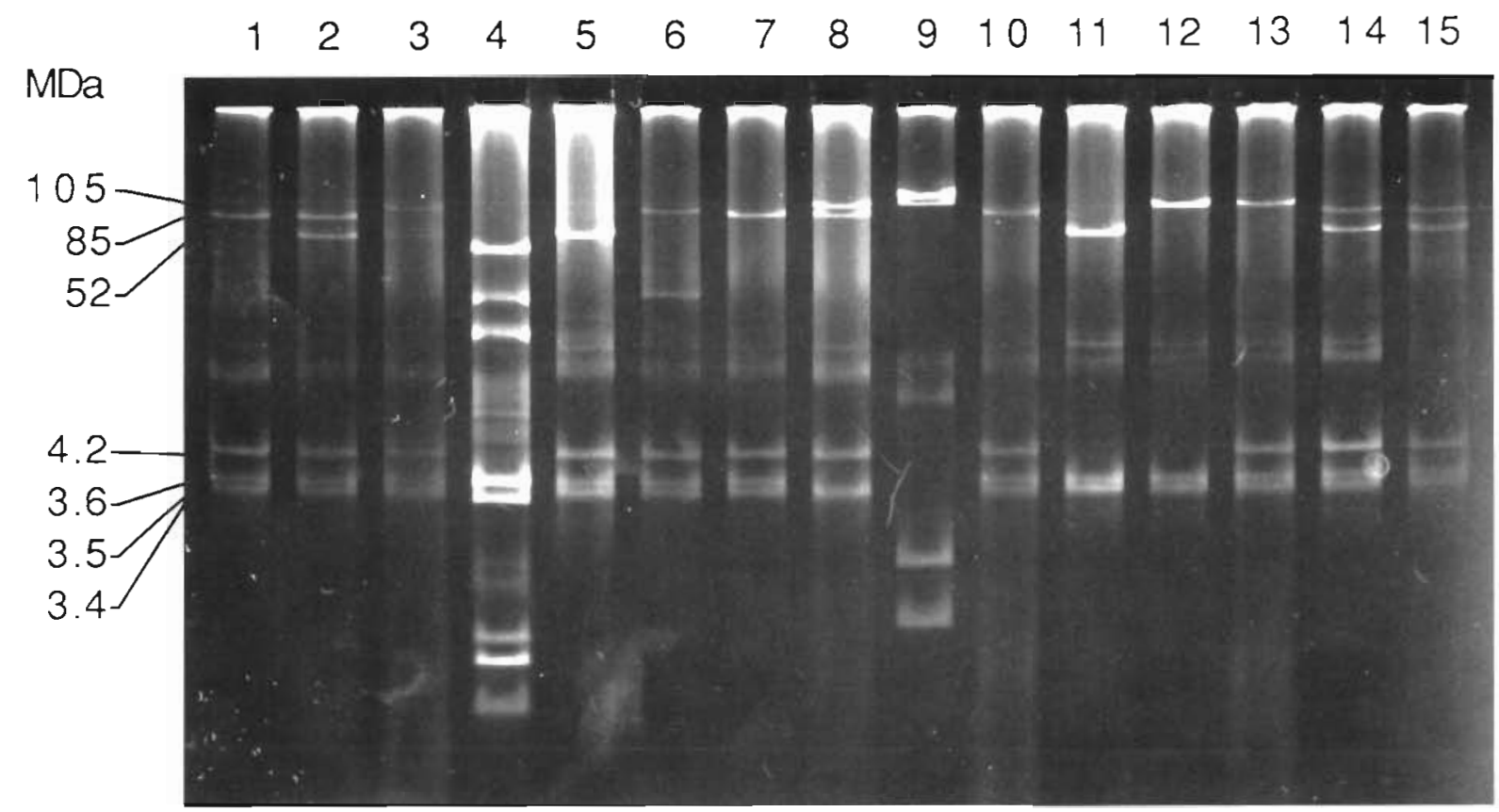

B
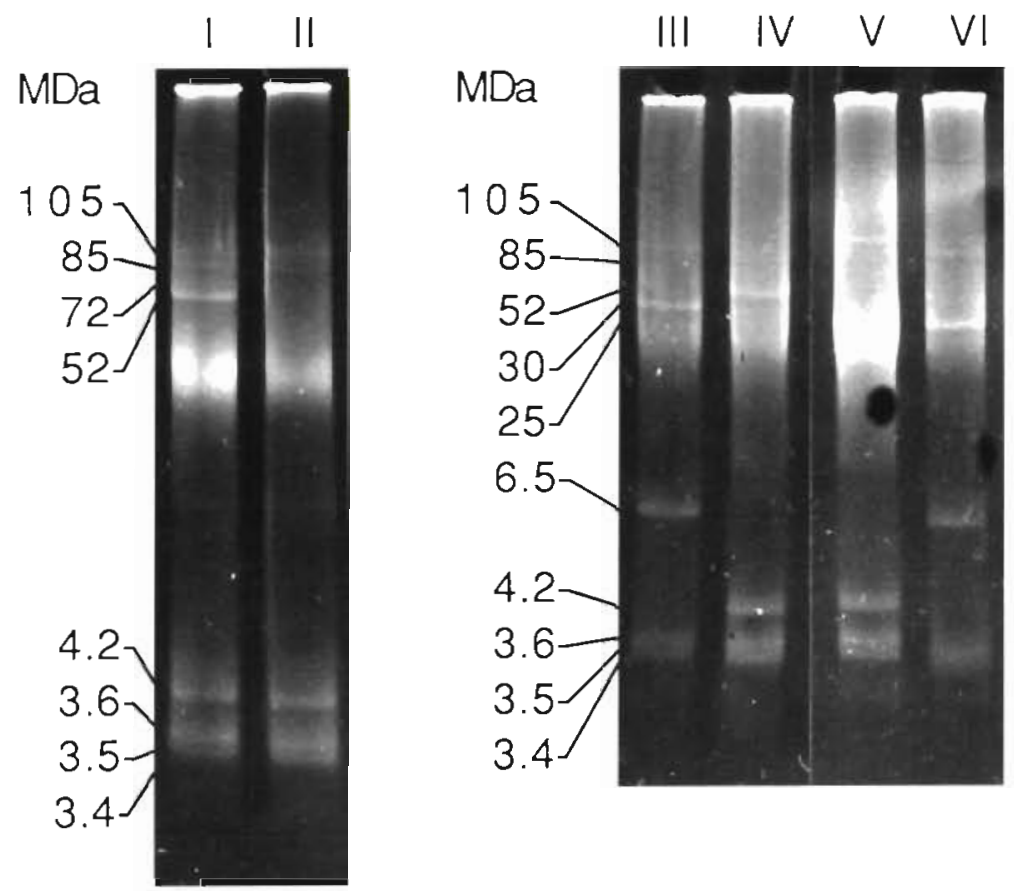

VII VIII

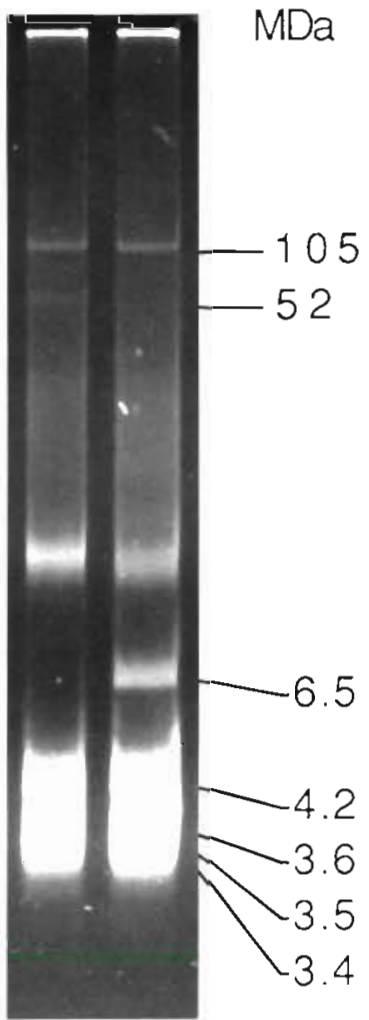

Fig. 1. Plasmid profiles of Aeromonas salmonicida ss salmonicida isolates after plasmid isolation by the Kado \& Liu (1981) method Plasmid sizes are given in megadaltons (MDa). (A) Lanes 1 to 3,5 to 8 , and 10 to 15 contain regular plasmid profiles of $A$. salmonicida ss salmonicida. Lane 4 contains standard plasmids from Escherichia coli V517 with sizes of 35.8, 4.8, 3.7. 3.4. 2.6. 2.0, 1.8 and 1.4 MDa. Lane 9 contains standard plasmids of 1.40 (pDK9) and $105 \mathrm{MDa}$. The isolates in lanes 11 and 12 both lack the 4.2 MDa plasmid. The isolate in lane 8 lacks the $3.6 \mathrm{MDa}$ plasmid. The 3.4 and $3.5 \mathrm{MDa}$ plasmids comigrate in this gel. Weak bands of the open circle plasmids of the small plasmids of 3.4 to $4.2 \mathrm{MDa}$ can be seen between the large and small plasmids. (B) Lane I contains all 4 large plasmid bands seen in A. salmonicida ss salmonicida in one profile. Lanes III and VI contaın intermediate sized plasmids (these are R-plasmids; data not shown) of 30 and $25 \mathrm{MDa}$, respectively, in addition to the regular plasmids of A. salmonicida ss salmonicida. The profiles in lanes III and VI contain a $6.5 \mathrm{MDa}$ plasmid instead of the 4.2 MDa plasmid commonly seen. Lane VIII contain a 6.5 MDa plasmid in addition to the regular plasmids seen in $A$. salmonicida ss salmonicida. Lanes II, IV, V and VII contain ordinary profiles of A. salmonicida ss salmonicida 
Table 2. Large plasmid profiles of isolates from kidney $(k)$, spleen ( $\mathrm{s}$ ), and muscle lesions ( $\mathrm{m}$ ) of salmonids from a single furunculosis outbreak at one farm. The plasmid isolation procedure for all the isolations reported in this table was the modified method of Kado \& Liu (1981)

\begin{tabular}{|c|c|c|}
\hline \multirow{2}{*}{ Fish no. } & \multicolumn{2}{|c|}{ Plasmid profile (MDa) } \\
\hline & First isolation & Second isolation ${ }^{a}$ \\
\hline $1 \mathrm{k}$ & $-{ }^{b}$ & 85 \\
\hline $\mathrm{s}$ & 85,52 & 105 \\
\hline $\mathrm{m}$ & 105 & 52 \\
\hline $2 \mathrm{k}$ & 105 & $105,85,52$ \\
\hline $\mathrm{s}$ & 105 & $105,85,52$ \\
\hline $\mathrm{m}$ & 105 & 105,85 \\
\hline $3 k$ & 105 & $105,85,52$ \\
\hline $\mathrm{s}$ & 105 & 85,52 \\
\hline $\mathrm{m}$ & 105 & 85 \\
\hline $4 \mathrm{k}$ & 105 & 85,52 \\
\hline$s$ & 105 & $-c$ \\
\hline $\mathrm{m}$ & 105 & $-^{c}$ \\
\hline $5 \mathrm{k}$ & 105 & 85,52 \\
\hline s & 105 & $105,85,52$ \\
\hline $\mathrm{m}$ & 105 & 105 \\
\hline $6 \mathrm{k}$ & 105 & $105,85,52$ \\
\hline$s$ & 105 & 52 \\
\hline $\mathrm{m}$ & 105,52 & 52 \\
\hline \multicolumn{3}{|c|}{$\begin{array}{l}\text { The second plasmid profile test was performed more } \\
\text { than } 10 \text { mo after the first one } \\
\text { 'Plasmid profiling was not performed } \\
\text { "The isolate was lost during storage }\end{array}$} \\
\hline
\end{tabular}

a second testing more than 10 mo later, all but one of the isolates yielded plasmid profiles that differed from the ones that were originally present (Table 2).

When plasmid profiles for a given isolate were repeatedly examined over time using the same plasmid isolation procedure (modified method of Kado \& Liu 1981), it was found that the number of large plasmid bands in a gel varied. For example, while strain $3736 / 89$ had only one large plasmid band of $105 \mathrm{MDa}$ when first investigated, it showed 3 bands of 52.85 and $105 \mathrm{MDa}$ the second time plasmid isolation was performed. After the third plasmid isolation, only 2 bands of 52 and $105 \mathrm{MDa}$ were visible in the gel.

The different plasmid profiles and their relative frequency of occurrence are presented in Table 3. Among the plasmid profiles made from the entire collection of isolates, one profile with a lone $105 \mathrm{MDa}$ plasmid band (in addition to the small plasmids) was the most frequently seen $(38.1 \%)$ (Table 3 ).

Of the 383 isolates, 159 were plasmid-profiled more than once. Of these, 116 isolates were plasmid-profiled twice with 80 of them ( $69 \%$ ) yielding plasmid profiles that differed between the 2 testings. After several plasmid isolations, the plasmid profiles with the $105 \mathrm{MDa}$ band were the most stable, with plasmid variation
Table 3. Occurrence and variation in profiles of large plasmids from isolates of Aeromonas salmonicida ss salmonicida. The plasmid isolation procedure used for all of the isolates in this table was the modified method of Kado \& Liu (1981)

\begin{tabular}{|c|c|c|}
\hline $\begin{array}{c}\text { Plasmid } \\
\text { profile (MDa) }\end{array}$ & $\begin{array}{l}\text { Occurrence } \\
\text { of profiles }\end{array}$ & $\begin{array}{l}\text { Isolates with } \\
\text { var profile }\end{array}$ \\
\hline 105 & $228(38.1)$ & $26 / 52$ \\
\hline 85 & $110(18.4)$ & $32 / 45$ \\
\hline 52 & $65(10.9)$ & $10 / 16$ \\
\hline 105,52 & $62(10.4)$ & $6 / 9$ \\
\hline 85,52 & $53(8.8)$ & $12 / 18$ \\
\hline $105,85,52$ & $28(6.3)$ & $7 / 7$ \\
\hline 105,85 & $24(4.0)$ & $2 / 3$ \\
\hline 72 & $6(1.0)$ & $5 / 5$ \\
\hline 72,52 & $6(1.0)$ & $1 / 2$ \\
\hline $105,85,72,52$ & $4(0.7)$ & $1 / 1$ \\
\hline 85,72 & $2(0.3)$ & $--^{c}$ \\
\hline $85,72,52$ & $1(0.2)$ & $1 / 1$ \\
\hline Total & $599^{\mathrm{d}}$ & $103 / 159$ \\
\hline \multicolumn{3}{|c|}{$\begin{array}{l}\text { Number of times a particular plasmid profile was } \\
\text { observed in all testings and (in parentheses), the per- } \\
\text { centage of times that a particular plasmid profile was } \\
\text { observed relative to the total number of times profiles } \\
\text { were prepared } \\
\text { bumber of isolates that yielded a plasmid profile on } \\
\text { retesting that differed from that on the initial testing re- } \\
\text { lative to the number of isolates that were retested. Note: } \\
\text { retesting was done from } 1 \text { to } 8 \text { times, depending on the } \\
\text { isolate } \\
\text { None of isolates with this plasmid profile was retested } \\
\text { dotal number of plasmid profiles observed as a result of } \\
\text { the original and repeat testings }\end{array}$} \\
\hline
\end{tabular}

occurring in only half of the isolates showing this profile (Table 3 ).

The Kado \& Liu (1981) method of plasmid isolation gave the best results with regard to the large plasmids. Use of a freshly prepared lysis solution with $\mathrm{pH}$ adjusted to 12.55 and incubation for lysis at $65^{\circ} \mathrm{C}$ for close to $1 \mathrm{~h}$ produced the clearest plasmid profiles. Extraction with acid phenol using the shortest possible contact time gave clear and reproducible results. Sometimes 2 successive extractions were necessary. The mini-Birnboim method gave a high yield of the small plasmids, but a low yield of DNA from the large ones. In addition, the mini-Birnboim method gave 1 extra band from each of the 4 small plasmids. These bands migrated more slowly than the supercoiled plasmid DNA, and probably represented a relaxed form of the small plasmids. In conclusion the modified method of Kado \& Liu (1981) gave the clearest and most easily read plasmid profiles of the 2 methods employed.

The amount of DNA in each of the large plasmid bands in a given isolate, visualized by the intensity of 
each band, often varied. When the large plasmid occurred as a single band, the band intensity was strongest.

A group of 4 small plasmids of $3.4,3.5,3.6$ and 4.2 MDa was seen in the majority of the 383 Aeromonas salmonicida ss salmonicida isolates investigated. The 2 smallest plasmids of 3.4 and $3.5 \mathrm{MDa}$ were seen in every isolate, while the $3.6 \mathrm{MDa}$ plasmid was lacking in 4 isolates (1\%), and the 4.2 MDa plasmid in 39 isolates $(10.2 \%)$. Nine of the 46 isolates $(20 \%)$ from countries other than Norway lacked the $4.2 \mathrm{MDa}$ plasmid. One of the isolates (Ft 337) lost the 4.2 MDa plasmid during the study. One isolate lacked both the 4.2 and 3.6 MDa plasmids.

Plasmids intermediate in size between the large and small plasmids were seen in $28(7.3 \%)$ of the strains investigated. These plasmids varied in size from 6.5 through $10,19,23,25,30,35,38$ and $40 \mathrm{MDa}$. No variation of the bands of plasmids of intermediate size were seen on repeated plasmid isolations. Sixteen isolates, all of them from Norway, had a $6.5 \mathrm{MDa}$ plasmid instead of the 4.2 MDa plasmid. One isolate had both the 4.2 MDa plasmid and the 6.5 MDa plasmid (Fig. 1). Of the isolates with a 6.5 MDa plasmid, 7 from the same local area in Norway had a $25 \mathrm{MDa}$ R-plasmid (Fig. 1) with 3 antibiotic resistance determinants. Another 5 of the strains with a $6.5 \mathrm{MDa}$ plasmid had a 30 MDa R-plasmid (Fig. 1) with a tetracycline resistance determinant, and were isolated from another local area on the western coast of Norway (data not shown). Of the 46 strains originating from outside. Norway included in this study, 9 harboured intermediate-sized plasmids.

The 2-dimensional electrophoresis method involving UV radiation of the gel after regular electrophoresis showed that the smaller plasmids migrated as expected in the second phase of the electrophoresis. However, the larger plasmid bands of $50 \mathrm{MDa}$ and more, did not migrate during the second phase of electrophoresis (data not shown).

Three different isolates that had all shown a $105 \mathrm{MDa}$ plasmid band in the first plasmid preparation were grown in 3 different broth media (BHIB, LB, and SWYP) before plasmid isolation. One isolate produced 2 large plasmid bands of 105 and 52 MDa in SWYP, while only the $105 \mathrm{MDa}$ band was produced in the 2 other media. Only the 105 MDa band was produced from the other 2 isolates.

Two strains (4190/88 3B and 3M) from the spleen and a muscle lesion, respectively, of the same fish which had shown varying plasmid profiles on repeated plasmid isolations were harvested at 20,22.5,43.5, 47 and $67 \mathrm{~h}$. The length of incubation time had no effect on plasmid profile (data not shown). The storage of purified plasmid DNA at $4{ }^{\circ} \mathrm{C}$ for periods of up to several weeks before agarose gel electrophoresis did not seem to affect the appearance of plasmid bands in agarose gel.

Electrophoresis of plasmids from bacteria lysed in the wells of the agarose gel did not give any large plasmid bands (data not shown).

No large plasmid bands could be detected after UV illumination, or following mechanical stress of isolated plasmid DNA using the aforementioned syringe and needle procedure (data not shown)

Large plasmid bands of all observed sizes, hybridized with the plasmid of 52 MDa from strain 2921/89 when the latter was used as probe. This strain had shown only this particular $52 \mathrm{MDa}$ plasmid band after several isolations. None of the control plasmids from E. coli hybridized with the probe (Table 4).

\section{DISCUSSION}

The plasmid content of the large number of Aeromonas salmonicida ss salmonicida isolates examined in this study was very homogeneous when all of the plasmids present in the organism were considered. Most of the variation that occurred was that involving the profiles ylelded by the large plasmid(s) (i.e. those ranging in size from 52 to $105 \mathrm{MDa}$ ). Unlike the single dominant plasmid profiles seen in Salmonella isolates during outbreaks of salmonellosis in man and animals (Holmberg et al. 1984, Olsvik et al. 1985, Sørum et al.

Table 4. Homology between the DNA of the $52 \mathrm{MDa}$ plasmid band of Aeromonas salmonicida ss salmonicida isolate 2921/89, used as radioactive labelled probe, and the large plasmid bands of other A salmonicida ss salmonicida isolates and plasmid DNA of 2 Escherichia coli strains

\begin{tabular}{|c|c|c|c|}
\hline Isolate & Origin $^{a}$ & Homology $y^{b}$ & No homology $y^{b}$ \\
\hline $2921 / 89$ & $\mathrm{~N}$ & 52 & \\
\hline $3736 / 89$ & $\mathrm{~N}$ & 85 & \\
\hline $2442 / 89$ & $\mathrm{~N}$ & 5285 & \\
\hline $2685 / 89$ & $N$ & 5285 & \\
\hline $250 / 86 \mathrm{Fi}$ & $N$ & 85 & \\
\hline $2893 / 85$ & $\mathrm{CH}$ & 85105 & \\
\hline $2755 / 85 \mathrm{~V}$ & DK & 5285 & \\
\hline $30 / 87$ & S & 85105 & \\
\hline $34 \mathrm{DK}$ & DK & 52 & \\
\hline $37 \mathrm{DK}$ & $\mathrm{DK}$ & 5285 & \\
\hline $42 \mathrm{DK}$ & DK & 105 & \\
\hline E. coli K 12 & & & $\mathrm{pDK} 9^{\mathrm{c}}$ \\
\hline E. coli $\vee 517$ & & & $\begin{array}{l}1.4,1.8,2.0,2.6,3.4, \\
3.7,4.8,35.8\end{array}$ \\
\hline \multicolumn{4}{|c|}{$\begin{array}{l}\text { N: Norway; CH: Switzerland; DK: Denmark; S: Sweden } \\
\text { bizes of plasmids in } \mathrm{MDa} \\
\text { pDK9 has a size of } 140 \mathrm{MDa}\end{array}$} \\
\hline
\end{tabular}


1990), the plasmid profiles in cases of furunculosis varied to a considerable degree within outbreaks, among isolates from a single diseased fish, and even within a given isolate. Our studies indicated that the large plasmids were susceptible to strees (both physical and mechanical), as was the large (170 MDa) plasmid of another fish pathogen, Vibrio salmonicida, investigated earlier by Sorum et al. (1992).

Susceptibility to physical and mechanical stress may explain why large plasmid profiles obtained using the gentle plasmid extraction technique of the Kado \& Liu (1981) procedure were superior to those that resulted when the harsher mini-Birnboim method was used. Other factors tested, including the effect of the growth medium, the effect of age of the culture, and the effect of length of storage of the isolated plasmid at $4{ }^{\circ} \mathrm{C}$ appeared not to account for the large plasmid variability.

Large plasmids have also been described from Aeromonas salmonicida ss salmonicida isolates by other workers. For example, Bast et al. (1988), in a study of 35 isolates, reported that 1 or more large plasmids (50 to $90 \mathrm{MDa}$ ) were always present, with some of the isolates possessing plasmids varying in size from 63 to 77 or from 77 to $83 \mathrm{MDa}$. Likewise, a large plasmid $(70$ to $145 \mathrm{~kb}$, equal to approximately 47 to $97 \mathrm{MDa}$ ) was also reported in each of 14 isolates studied by Belland \& Trust (1989). Further, based on restriction enzyme analysis, there was considerable relatedness between these large plasmids.

In the present study, the hybridization tests indicated that all of the large plasmids shared common sequences, thus supporting the possibility that the different large plasmid bands may actually have represented different configurations of the same plasmid. Another possibility is that there were in fact up to 4 different large plasmids, each of them with common sequences, but that the individual plasmids did not always replicate to the stage where visible bands were produced. If the latter is true, this would constitute a hitherto unknown method of plasmid expression. Although unequivocal explanations for the large plasmid variability observed in this study are still not available, it is clear that the large plasmids would be useless as epizootiological markers in view of their 'within-isolate' variability.

When the intermediate and small-size plasmids carried by Aeromonas salmonicida ss salmonicida are considered, they appear to provide only limited potential for use as epizootiological markers. As already mentioned, the plasmids of intermediate size (6.5 to $40 \mathrm{MDa}$ ) appeared to be stable on repeated testing but only $28(7.3 \%)$ of the isolates, 9 of them from outside of Norway, carried these plasmids. The scope for unique plasmid profiles with respect to intermediate-size plas- mids was thus rather limited. The same conclusion also appears warranted with respect to epizootiological usefulness of the small plasmids. It also has already been indicated that most of the isolates carried 4 small (3.4 to 4.2 MDa in size) plasmids, only $1 \%$ (4) of the isolates lacking the 3.6 MDA plasmid, $10 \%$ (39) of the isolates lacking the $4.2 \mathrm{MDa}$ plasmid, and $0.003 \%$ (1) of the isolates lacking both of these plasmids. These data indicate that the isolates were very homogeneous with respect to the small plasmids. Further, some of this variability may have developed after collection and holding of the isolates. (One isolate, for example, lost its 4.2 MDa plasmid during the study and a number of the other isolates that lacked this plasmid had been held in culture collections for some time.) Because of the homogeneity in the small plasmid profiles, the value of the small plasmids as epizootiological markers would be limited.

In summary, as a result of our 6 yr of study with 383 isolates of Aeromonas salmonicida ss salmonicida we conclude that the plasmid content of this organism is remarkably uniform and that, except in the limited number of cases where plasmid additions or deletions occur, their usefulness for epizootiological purposes is limited. The high degree of variability observed with the large plasmids was of no value for epizootiological work because the variability occurred within isolates.

Acknowledgements. We gratefully thank the following for donating isolates of Aeromonas salmonicida for the study: $\mathrm{Dr}$ A. McKay, Marine Laboratory. Aberdeen, Scotland; Dr M. Alexander, Institute of Aquaculture, University of Stirling, Stirling, Scotland; Dr P. Vestergård, Statens Veterinære Serumlaboratorium, Århus, Denmark; Dr Inger Dalsgaard, Danish Institute for Fisheries and Marine Research, Royal Veterinary and Agricultural University, Copenhagen, Denmark; Dr C. Michel, Institut National de la Recherche Agronomique, Jouy-en-Josas, France; Dr J. McArdle, Fisheries Research Centre, Dublin, Ireland; Dr O. Ljungberg, Statens Veterinzermedicinska Anstalt, Uppsala, Sweden; and Dr T B. Jossund, Oppland, Norway. We acknowledge the technical assistance of Anne Berit Hvaal and Kari Dommarsnes. This study was supported by a grant from the Norwegian Agricultural Sciences Foundation to H.S.

\section{LITERATURE CITED}

Austin, B., Austin, D. A. (1987). Bacterial fish pathogens: disease in farmed and wild fish. Ellis Horwood Ltd, Chichester, p. 111-195

Bast, L., Daly, J. G., DeGrandis, S. A., Stevenson, R. M. W (1988). Evaluation of profiles of Aeromonas salmonicida as epidemiological markers of furunculosis infections in fish. J. Fish Dis. 11: 133-145

Belland, R. J., Trust, T. J. (1989). Aeromonas salmonicida plasmids: Plasmid-directed synthesis of proteins in vitro and in Escherichia coli minicells. J. gen. Microbiol. 135: 513-524

Birnboim, H. C., Doly, J. (1979). A rapid alkaline extraction procedure for screening recombinant plasmid DNA. Nucleic Acids Res. 7: 1513-1523 
Elmerich, C. (1990). A brief survey of the plasmid world. Res. Microbiol. 141.617-619

Hackett, J. L., Lynch, W. H., Paterson, W. D., Coombs, D. H (1984). Extracellular protease, extracellular haemolysin, and virulence in Aeromonas salmonicida. Can. J. Fish. Aquat. Sci. 41: $1354-1360$

Hendrie, M. S., Hodgkiss, W., Shewan, J. M. (1970). The identification, taxonomy and classification of luminous bacteria. J. gen. Microbiol. 64: 151-169

Hintermann, G., Fischer, H.-M., Crameri, R. Hütter, R. (1981). Simple procedure for distinguishing $\mathrm{CCC}, \mathrm{OC}$, and $\mathrm{L}$ forms of plasmid DNA by agarose gel electrophoresis. Plasmid 5: 371-373

Holmberg, S. D., Wachsmuth, I. K., Hickman-Brenner, F. W. Cohen, M. L. (1984). Comparison of plasmid profile analysis, phage typing, and antimicrobial tibility testing in characterizing Salmonella typhimurium isolates from outbreaks. J. clin. Microbiol. 19: $100-104$

Kado, C. I., Liu, S.-T. (1981). Rapid procedure for detection and isolation of large and small plasmids. J. Bacteriol. 145: $1365-1373$

Macrina, F. L., Kopecko, D. J., Jones, K. R., Ayers, D. J., McCowen, S. M. (1978). A multiple plasmid-containing Escherichia coli strain: convenient source of size reference plasmid molecules. Plasmid 1: 417-420

Responsible Subject Editor: T. Evelyn, Nanaimo, B.C., Canada
Maniatis, T., Fritsch, E. F., Sambrook, J. (1982). Molecular cloning: a laboratory manual. Cold Spring Harbor Laboratory, Cold Spring Harbor, NY

Olsvik, Ø., Sørum, H., Birkness, K., Wachsmuth, K., Fjølstad, M. Lassen, J., Fossum, K., Feeley, J. C. (1.985). Plasmid characterization of Salmonella typhimurium transmitted from animals to humans. J clin. Microbiol. 22: 336-338

Sørum, H. Bovre, K., Bukholm, G., Lassen, J., Olsvik, $\varnothing$. (1990). A unique plasmid profile characterizing Salmonella enteritidis isolates from patients and employees in a hospital. APMIS 98: 25-29

Sørum, H., Myhr, E., Zwicker, B. M., Lillehaug, A. (1993) Comparison by plasmid profiling of Vibrio salmonicida strains isolated from diseased fish from different North European and Canadian coastal areas of the Atlantic Ocean. Can. J. Fish. Aquat. Sci. 50: 247-250

Sorum, H., Poppe, T T., Oisvik, Ø. (1988). Plasmids in Vibrio salmonicida isolated from salmonids with Hemorrhagic syndrome (Hitra disease). J. clin. Microbiol. 26: 1679-1.683

Sorum, H., Roberts, M. C., Crosa, J. H. (1992). Identification and cloning of a tetracycline resistance gene from the fish pathogen Vibrio salmonicida. Antimicrob. Agents Chemother. 36: 611-615

Toranzo, A. E., Barja, J. L. Colwell, R. R. Hetrick. F. M. (1983) Characterization of plasmids in bacterial fish pathogens Infect. Immun. 39: 184-192

Manuscript first received: October 7, 1992

Revised version accepted: May 7, 1993 